\title{
PENERAPAN SAW-TOPSIS DALAM ANALISIS RASIO KEUANGAN UNTUK MENUNJANG KEPUTUSAN BERINVESTASI SAHAM
}

\author{
Angger Binuko Paksi ${ }^{1)}$, Ema Utami ${ }^{2}$, Henderi $^{3)}$ \\ 1), 2) Magister Teknik Informatika STMIK AMIKOM Yogyakarta \\ ${ }^{3)}$ S3 Ilmu Komputer Universitas Gadjah Mada Yogyakarta \\ Jl Ring road Utara, Condongcatur, Sleman, Yogyakarta 55281 \\ Email :angger.binuko@gmail.com ${ }^{I)}$,ema.u@amikom.ac.id ${ }^{2}$, henderi@mail.ugm.ac.id ${ }^{3}$
}

\begin{abstract}
Abstrak
Investasi saham merupakan satu dari sekian banyak pilihan berinvestasi. Dalam berinvestasi saham dibutuhkan suatu analisis dan tindakan yang tepat agar seorang investor dapat berinvestasi sesuai kebutuhannya. Salah satu caranya dengan analisis fundamental. Analisis fundamental merupakan metode analisis yang menitikberatkan pada data-data kunci yang ada dalam laporan keuangan suatu perusahaan untuk menilai kinerja keuangan perusahaan. Penelitian ini bertujuan untuk merancang proses analisis fundamental saham berdasarkan analisis rasio keuangan, metode SAW dan metode TOPSIS. Analisis rasio keuangan secara umum meliputi rasio likuiditas, rasio solvabilitas, rasio aktivitas, rasio profitabilitas dan rasio pasar. Bilangan fuzzy digunakan dalam metode SAW dan TOPSIS untuk memberikan efektivitas dalam menentukan nilai matriks keputusan. Metode SAW digunakan untuk mencari nilai matriks ternormalisasi untuk setiap kriteria dan metode TOPSIS digunakan untuk mencari solusi/alternatif berdasarkan nilai matriks ternormalisasi. Kemudian rancangan diterapkan dalam bentuk sistem pendukung keputusan berbasis aplikasi web. Pengujian dilakukan dengan 30 data laporan keuangan pada sektor properti dalam periode 2013-2015. Dari hasil pengujian akurasi menggunakan korelasi pemeringkatan Spearman berdasarkan model Springate dengan data uji pada periode 2013-2015 didapatkan hasil rata-rata 90\%.
\end{abstract}

Kata kunci: Analisis Fundamental Saham, Rasio Keuangan, Bilangan Fuzzy, SAW, TOPSIS, Springate, Spearman, Sistem Pendukung Keputusan.

\section{Pendahuluan}

Investasi merupakan suatu langkah seseorang dalam pemenuhan kebutuhan di masa yang akan datang. Investasi saham merupakan satu dari sekian banyak pilihan investasi yang semakin diminati oleh berbagai kalangan. Sosialisasi serta akses yang semakin mudah, menjadi sarana bagi siapa saja untuk bisa ikut serta dalam berinvestasi saham. Teratur, aman dan efisien menjadikan saham sebagai investasi yang menarik setelah deposito, obligasi, properti, dan emas. Hampir semua negara saat ini memiliki bursa saham, dengan pengkodean indeks saham masing-masing. Intinya, bursa saham mencerminkan kemajuan perekonomian dari suatu negara. Dalam berinvestasi saham, pergerakan nilai saham suatu perusahaan dipengaruhi oleh beberapa faktor. Dengan demikian dibutuhkan suatu analisis dan tindakan yang tepat dalam berinvestasi di pasar saham agar seorang investor dapat berinvestasi sesuai kebutuhannya. Prediksi pergerakan suatu saham dapat dilakukan dengan dua cara, yaitu dengan menggunakan analisis fundamental dan analisis teknikal.

Analisis fundamental merupakan metode analisis yang menggunakan studi tentang keadaan ekonomi, industri, dan kondisi perusahaan untuk menentukan nilai wajar dari harga saham perusahaan (Hendy, 2008). Salah satu teknik analisis fundamental yang umum digunakan adalah analisis rasio keuangan. Analisis rasio keuangan ini didasarkan pada fundamental ekonomi suatu perusahaan, yang secara teknis akan menitik beratkan pada rasio keuangan di dalam laporan keuangan perusahaan. Sebagian pakar berpendapat analisis fundamental lebih cocok untuk membuat keputusan dalam memilih saham perusahaan mana yang dibeli untuk jangka panjang [1].

Analisis rasio keuangan saat ini masih banyak dilakukan dengan perhitungan manual, sehingga akan memakan cukup banyak waktu untuk melakukan perhitungan dan pemilihan saham yang layak untuk dijadikan pilihan berinvestasi, namun adanya sebuah sistem pendukung keputusan yang dapat mengolah data-data dari analisis rasio keuangan akan membantu para investor dalam proses pemilihan berinvestasi saham lebih efektif dan efisien. Menurut Hery (2015) perhitungan rasio seharusnya juga didasarkan pada data laporan keuangan yang sudah diaudit oleh akuntan independen [2]. Oleh sebab itu dalam penelitian ini laporan keuangan yang dijadikan sumber data adalah laporan keuangan tahunan yang telah dinyatakan lolos audit dan telah disediakan oleh pihak Bursa Efek Indonesia pada situs resmi www.idx.co.id, sehingga data-data yang akan digunakan dalam penelitian ini telah terjamin validitasnya.

Menurut Henry Wibowo (2010) dalam penelitian berjudul MADM-Tool : Aplikasi Uji Sensitivitas untuk Model MADM Menggunakan Metode SAW dan TOPSIS, kedua metode tersebut memiliki konsep sederhana, mudah dipahami, komputasinya efisien dan memiliki kemampuan untuk mengukur kinerja relatif dari 
alternatif-alternatif keputusan dalam bentuk matematis yang sederhana. Metode SAW digunakan untuk mencari nilai matriks ternormalisasi $\mathrm{R}$ untuk setiap kriteria. Sedangkan metode TOPSIS digunakan untuk mencari solusi atau alternatif berdasarkan hasil nilai matriks ternormalisasi dari metode SAW [3].

Berdasarkan hasil observasi pada penelitian-penelitian sebelumnya maka pada penelitian ini penulis akan fokus pada rumusan masalah berikut:

1. Seperti apa rancangan proses analisis fundamental saham berdasarkan analisis rasio keuangan, metode SAW dan metode TOPSIS?

2. Apakah penerapan metode SAW dan TOPSIS untuk mengolah hasil perhitungan analisis rasio keuangan dapat menghasilkan rekomendasi alternatif saham?

Berdasarkan observasi terhadap pustaka dan penelitian serupa, penggunaan metode SAW dan TOPSIS dimungkinkan untuk diterapkan dalam penelitian ini karena kebutuhan dalam menentukan nilai bobot masingmasing kriteria (rasio keuangan) dapat ditangani dengan metode SAW dan proses pemeringkatan alternatif saham dapat ditangani dengan metode TOPSIS. Dengan penerapan metode SAW dan TOPSIS dalam analisis rasio keuangan, diharapkan dapat membantu para investor dalam menentukan pilihan berinvestasi saham lebih efektif dan efisien. Dan berdasarkan penelitian Yan Satria Setyawan, et al. (2015) pengujian pada penelitian ini akan menggunakan metode analisis rasio keuangan sebagai pembanding dari metode yang digunakan pada penelitian ini. Dimana metode yang dapat digunakan sebagai pembanding adalah metode Springate, kemudian pengukuran akurasi akan menggunakan koefisien korelasi pemeringkatan Spearman [4].

\section{Analisis Rasio Keuangan}

Analisis rasio keuangan merupakan alat untuk mengevaluasi kinerja perusahaan berdasarkan data-data yang ada pada laporan keuangan. Tabel 1 menunjukkan jenis-jenis rasio yang akan dijadikan fokus pembahasan dalam penelitian ini [5][6].

Tabel 1. Kelompok rasio keuangan

\begin{tabular}{|l|l|c|}
\hline Kelompok Rasio & Jenis rasio & \multicolumn{1}{c|}{ Rumus } \\
\hline Rasio Likuiditas & Current Ratio & $\frac{\text { Aset Lancar }}{\text { Kewajiban Jangka Pendek }}$ \\
\cline { 2 - 3 } & Quick Ratio & $\frac{\text { (Aset Lancar - Persediaan) }}{\text { Kewajiban Jangka Pendek }}$ \\
\cline { 2 - 3 } & Cash Ratio & $\frac{\text { Kas dan Setara Kas }}{\text { Rewajio Solvabilitas Jangka Pendek }}$ \\
\cline { 2 - 3 } & Debt to Asset Ratio & $\frac{\text { Total Kewajiban }}{\text { Total Aset }}$ \\
\cline { 2 - 3 } & Debt to Equity Ratio & $\frac{\text { Total Kewajiban }}{\text { Total Ekuitas }}$ \\
\cline { 2 - 3 } & $\begin{array}{l}\text { Long Term Debt to Equity } \\
\text { Ratio }\end{array}$ & $\frac{\text { Kewajiban Jangka Panjang }}{\text { Total Ekuitas }}$ \\
\cline { 2 - 3 } & Equity Multiplier & $\frac{\text { Total Aset }}{\text { Total Ekuitas }}$ \\
\hline
\end{tabular}

\begin{tabular}{|c|c|c|}
\hline \multirow[t]{5}{*}{ Rasio Aktivitas } & Accounts Receivable Turnover & $\frac{\text { Penjualan Neto }}{\text { Rata-rata Piutang }}$ \\
\hline & Inventory Turnover & $\frac{\text { Beban Pokok Penjualan }}{\text { Rata-rata Persediaan }}$ \\
\hline & Working Capital Turnover & $\frac{\text { Penjualan Neto }}{\text { Rata-rata Aset Lancar }}$ \\
\hline & Fixed Assets Turnover & $\frac{\text { Penjualan Neto }}{\text { Rata-rata Aset Tetap }}$ \\
\hline & Total Assets Turnover & $\frac{\text { Penjualan Neto }}{\text { Rata-rata Total Aset }}$ \\
\hline \multirow[t]{5}{*}{\begin{tabular}{|l} 
Rasio \\
Profitabilitas
\end{tabular}} & Return on Assets & $\frac{\text { Laba Bersih }}{\text { Total Aset }}$ \\
\hline & Return on Equity & $\frac{\text { Laba Bersih }}{\text { Total Ekuitas }}$ \\
\hline & Gross Profit Margin & $\frac{\text { Laba Kotor }}{\text { Penjualan Neto }}$ \\
\hline & Operating Profit Margin & $\frac{\text { Laba Usaha }}{\text { Penjualan Neto }}$ \\
\hline & Net Profit Margin & $\frac{\text { Laba Bersih }}{\text { Penjualan Neto }}$ \\
\hline \multirow[t]{2}{*}{ Rasio Pasar } & Price Earnings Ratio & $\frac{\text { Harga Saham Per Lembar }}{\text { Laba Per Saham }}$ \\
\hline & Price to Book Value Ratio & $\frac{\text { Harga Saham Per Lembar }}{\left(\frac{\text { Total Ekuitas }}{\text { Jumlah Saham Beredar }}\right)}$ \\
\hline
\end{tabular}

\section{Fungsi Keanggotaan Fuzzy}

Representasi linear naik, dimulai pada nilai domain yang memiliki derajat keanggotaan nol (0) bergerak ke kanan menuju ke nilai domain yang memiliki derajat keanggotaan lebih tinggi (Gambar 1)[7].

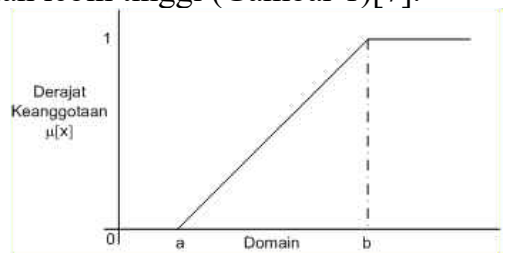

Gambar 1. Representasi linear naik

Fungsi keanggotaan:

$\mu[\mathrm{x}]= \begin{cases}0 ; & x \leq a \\ (x-a) /(b-a) ; & a \leq x \leq b \\ 1 ; & x \geq b\end{cases}$

Representasi linear turun, dimulai dari nilai domain pada derajat keanggotaan tertinggi pada sisi kiri, kemudian bergerak menurun ke nilai domain yang memiliki derajat keanggotaan lebih rendah (Gambar 2)[7].

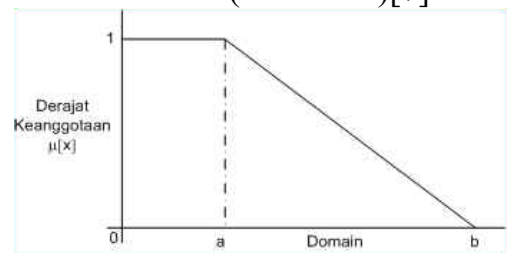

Gambar 2. Representasi linear turun

Fungsi keanggotaan:

$\mu[\mathrm{x}]= \begin{cases}1 ; & x \leq a \\ (b-x) /(b-a) ; & a \leq x \leq b \\ 0 ; & x \geq b\end{cases}$ 


\section{Metode SAW}

Prosedur dalam penerapan metode SAW yaitu [8]:

1. Membuat matriks keputusan ternormalisasi berdasarkan persamaan:

$$
r_{i j}= \begin{cases}\frac{X_{i j}}{\max X_{i j}} & ; \mathrm{jika} \mathrm{j}=\text { keuntungan }(\text { benefit }) \ldots . .(3) \\ \frac{\min X_{i j}}{X_{i j}} & ; \mathrm{jika} \mathrm{j}=\text { biaya }(\text { cost }) \ldots \ldots \ldots \ldots \ldots \ldots . . . . . .\end{cases}
$$

Dimana dengan $\mathrm{r}_{\mathrm{ij}}$ adalah rating kinerja

ternormalisasi dari alternatif $A_{i}$ pada atribut $C_{j}: I=$ $1,2 \ldots, \mathrm{n}$

2. Menentukan nilai preferensi untuk setiap alternatif $\left(V_{i}\right)$ dengan persamaan:

$$
V_{i}=\sum_{j=1}^{n} w_{j} r_{i j}
$$

\section{Metode TOPSIS}

Ada beberapa langkah kerja dalam TOPSIS yaitu [8]:

1. Membuat matriks keputusan ternormalisasi, TOPSIS membutuhkan rating kinerja setiap alternatif $\mathrm{A}_{i}$ pada setiap kriteria $\mathrm{C}_{\mathrm{i}}$ yang ternormalisasi, berdasarkan persamaan:

$$
r \mathrm{ij}=\frac{x_{i j}}{\sqrt{\sum_{i=1}^{m} x_{i j}^{2}}} ; \mathrm{i}=1,2, \ldots, \mathrm{m} ; \text { dan } \mathrm{j}=1,2, \ldots, \mathrm{n}
$$

2. Membuat matriks keputusan ternormalisasi terbobot ( $\mathrm{y}_{\mathrm{ij}}$ ) dengan mengalikan bobot $\mathrm{w}_{\mathrm{i}}$ dengan rating kerja $\mathrm{r}_{\mathrm{ij}}$, berdasarkan persamaan:

$Y \mathrm{ij}=w \mathrm{i} r \mathrm{ij} ; \mathrm{i}=1,2, \ldots, \mathrm{m} ;$ dan $\mathrm{j}=1,2, \ldots, \mathrm{n} \ldots \ldots .(7)$

3. Menentukan matriks solusi ideal positif $\left(A^{+}\right)$dan matriks solusi ideal negatif $\left(A^{-}\right)$berdasarkan rating bobot ternormalisasi $\mathrm{y}_{\mathrm{ij}}$.

$A^{+}=\left(y_{1}^{+}, y_{2}^{+}, \ldots, y_{n}^{+}\right)$
$A^{-}=\left(y_{1}^{-}, y_{2}^{-}, \ldots, y_{n}^{-}\right)$ dengan,

$$
\begin{aligned}
& y_{J}^{+}= \begin{cases}\max _{i} y_{i j} & ; \mathrm{jika} \mathrm{j}=\text { keuntungan (benefit) } \\
\min _{i} y_{i j} & ; \mathrm{jika} \mathrm{j}=\text { biaya }(\text { cost })\end{cases} \\
& y_{J}^{-}= \begin{cases}\max _{i} y_{i j} & ; \mathrm{jika} \mathrm{j}=\operatorname{keuntungan} \text { (benefit) } \\
\min _{i} y_{i j} & ; \mathrm{jika} \mathrm{j}=\text { biaya }(\text { cost })\end{cases} \\
& \mathrm{j}=1,2, \ldots, \mathrm{n}
\end{aligned}
$$

4. Menentukan jarak antara nilai setiap alternatif dengan matriks solusi ideal positif dan ideal negatif.

Jarak antara alternatif $A_{i}$ dengan solusi ideal positif dirumuskan dalam persamaan:

$$
D_{i}^{+}=\sqrt{\sum_{j=1}^{n}\left(y_{i j}-y_{i j}^{+}\right)^{2}}
$$

Jarak antara alternatif $A_{i}$ dengan solusi ideal negatif dirumuskan dalam persamaan:

$$
D_{i}^{-}=\sqrt{\sum_{j=1}^{n}\left(y_{i j}-y_{i j}^{-}\right)^{2}}
$$

5. Menentukan nilai preferensi untuk setiap alternatif $\left(V_{i}\right)$ dengan persamaan:

$$
V_{i}=\frac{D^{-}}{D_{i}^{-}+D_{i}^{+}} ; 0<\mathrm{V}_{\mathrm{i}}<1 \text { dan } \mathrm{i}=1,2,3, \ldots, \mathrm{n}
$$

\section{Model Springate}

Springate menggunakan langkah analisis diskriminasi ganda untuk memilih empat dari 19 rasio keuangan populer yang terbaik dibedakan antara bisnis yang sehat dan yang benar-benar gagal. Springate melakukan tes terhadap 40 perusahaan dan mendapatkan nilai akurasi sebesar 92.5\% (Frank Vickers, 2006). Metode Spingate dirumuskan dalam suatu formula sebagai berikut [9]:

$\mathrm{S}=1.03 \mathrm{~A}+3.07 \mathrm{~B}+0.66 \mathrm{C}+0.4 \mathrm{D}$ dimana; $\mathrm{A}=$ Modal Kerja / Total Aset

$$
\begin{aligned}
& \text { B }=\text { Laba Sebelum Bunga dan Pajak / Total Aset } \\
& \text { C }=\text { Laba Sebelum Pajak / Total Liabilitas } \\
& \text { D }=\text { Penjualan / Total Aset }
\end{aligned}
$$

\section{Korelasi Pemeringkatan Spearman}

Koefisien korelasi Spearman digunakan untuk mengetahui derajat keeratan dua variabel yang memiliki skala pengukuran minimal [10].

$$
r_{s}=1-\frac{6 \sum d_{i}^{2}}{n\left(n^{2}-1\right)}
$$

dimana; $r_{s}=$ koefisien korelasi Spearman

$$
\begin{aligned}
& d_{i}=\text { selisih ranking tiap pengamatan } \\
& \mathrm{n}=\text { banyaknya pengamatan }
\end{aligned}
$$

\section{Pembahasan}

Laporan keuangan yang telah diunduh dari situs resmi Bursa Efek Indonesia (www.idx.co.id) akan diolah menggunakan analisis rasio keuangan untuk mendapatkan nilai rasio-rasio keuangan, kemudian akan diproses dengan dengan metode SAW-TOPSIS untuk menghasilkan suatu rekomendasi dari alternatif yang ada. Ada 5 alternatif saham yang akan dijadikan contoh pembahasan dalam penelitian ini, yaitu Alam Sutera Realty Tbk. (ASRI), Bumi Serpong Damai Tbk. (BSDE), Kawasan Industri Jababeka Tbk. (KIJA), Summarecon Agung Tbk. (SMRA), Wijaya Karya (Persero) Tbk. (WIKA).

\subsection{Analisis Sistem}

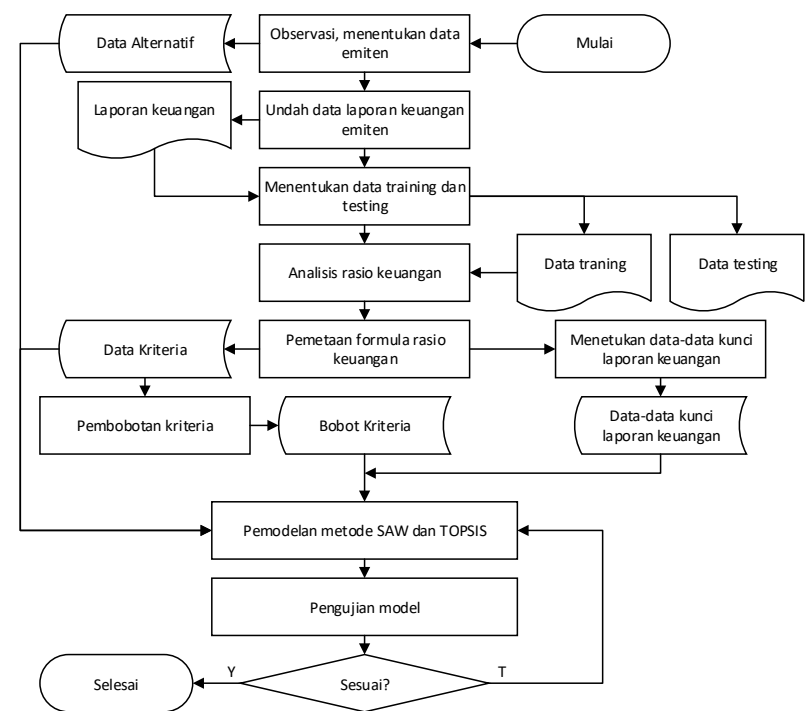

Gambar 3. Skema tahapan analisis sistem 


\subsection{Analisis Rasio Keuangan}

Dari data laporan keuangan setiap alternatif emiten pada tahun 2013 dan dilakukan perhitungan maka didapatkan data-data nilai rasio keuangan seperti pada Tabel 2:

Tabel 2. Hasil analisis rasio keuangan

\begin{tabular}{|c|l|r|r|r|r|r|}
\hline \multicolumn{2}{|c|}{ RASIO LIKUIDITAS } & ASRI & BSDE & KIJA & SMRA & WIKA \\
\hline C1 & Current Ratio & 0.753 & 2.667 & 2.867 & 1.280 & 1.095 \\
\hline C2 & Quick Ratio & -0.118 & 1.811 & 2.466 & 0.674 & 0.942 \\
\hline C3 & Cash Ratio & 0.239 & 0.976 & 0.340 & 0.505 & 0.190 \\
\hline RASIO SOLVABILITAS & ASRI & BSDE & KIJA & SMRA & WIKA \\
\hline C4 & Debt to Asset Ratio & 0.630 & 0.406 & 0.493 & 0.659 & 0.744 \\
\hline C5 & Debt to Equity Ratio & 1.706 & 0.683 & 0.972 & 1.933 & 2.903 \\
\hline C6 & Long Term Debt to Equty Ratio & 1.009 & 0.352 & 0.553 & 0.850 & 0.641 \\
\hline C7 & Equity Multiplier & 2.706 & 1.683 & 1.972 & 2.933 & 3.903 \\
\hline RASIO AKTIVITAS & ASRI & BSDE & KIJA & SMRA & WIKA \\
\hline C 8 & Accounts Receivable Turnover & 58.469 & 59.337 & 10.940 & 20.146 & 4.978 \\
\hline C9 & Inventory Turnover & 0.601 & 0.439 & 2.363 & 0.661 & 9.339 \\
\hline C10 & Working Capital Turnover & 1.099 & 0.566 & 0.580 & 0.666 & 1.559 \\
\hline C11 & Fixed Assets Turnover & 4.880 & 13.458 & 1.272 & 12.909 & 8.417 \\
\hline C12 & Total Assets Turnover & 0.290 & 0.292 & 0.357 & 0.334 & 1.007 \\
\hline RASIO PROFITABILITAS & ASRI & BSDE & KIJA & SMRA & WIKA \\
\hline C13 & Return on Assets & 0.075 & 0.129 & 0.013 & 0.080 & 0.050 \\
\hline C14 & Return on Equity & 0.203 & 0.217 & 0.025 & 0.235 & 0.193 \\
\hline C15 & Gross Profit Margin & 0.499 & 0.726 & 0.428 & 0.525 & 0.111 \\
\hline C16 & Operating Profit Margin & 0.416 & 0.507 & 0.312 & 0.329 & 0.102 \\
\hline C17 & Net Profit Margin & 0.294 & 0.506 & 0.038 & 0.268 & 0.053 \\
\hline RASIO PASAR & ASRI & BSDE & KIJA & SMRA & WIKA \\
\hline C18 & Price Earnings Ratio & 9.637 & 11.377 & 38.523 & 10.209 & 17.002 \\
\hline C19 & Price to Book Value Ratio & 1.585 & 2.282 & 0.928 & 2.416 & 3.006 \\
\hline
\end{tabular}

Dari proses analisis rasio keuangan didapatkan data-data kriteria diantaranya adalah: Current Ratio, Quick Ratio, Cash Ratio, Debt to Asset Ratio, Debt to Equity Ratio, Long Term Debt to Equty Ratio, Equity Multiplier, Accounts Receivable Turnover, Inventory Turnover, Working Capital Turnover, Fixed Assets Turnover, Total Assets Turnover, Return on Assets, Return on Equity, Gross Profit Margin, Operating Profit Margin, Net Profit Margin, Price Earnings Ratio, dan Price to Book Value Ratio.

\subsection{Pemodelan SAW-TOPSIS}

\section{Menentukan matriks keputusan}

Dalam rasio keuangan ada acuan untuk menilai kinerja keuangan suatu perusahaan yang disebut dengan rata-rata industri. Jika rata-rata industri sebagai nilai tengah dalam derajat keanggotaan (Gambar 4 dan Gambar 5) maka didapatkan persamaan dengan mengadopsi fungsi keanggotaan linear untuk menghitung nilai matriks keputusan (persamaan 15 dan persamaan 16).

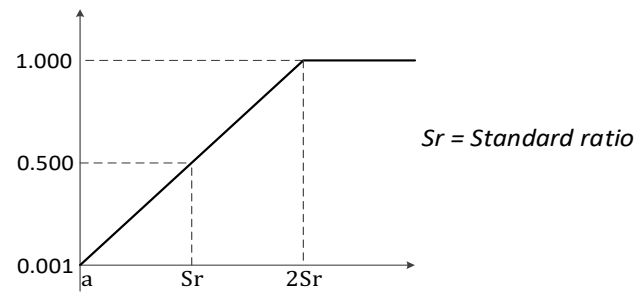

Gambar 4. Representasi matriks keputusan linear naik

Fungsi matriks keputusan linear naik:

$$
\mu[\mathrm{x}]= \begin{cases}1.000 ; & x \leq a \\ (x-a) /(2 S r-a) ; & a \leq x \leq b \\ 0.001 ; & x \geq b\end{cases}
$$

dimana $\mathrm{a}=0$ dan nilai $\mu[\mathrm{x}]$ tidak boleh lebih dari 1.000 .

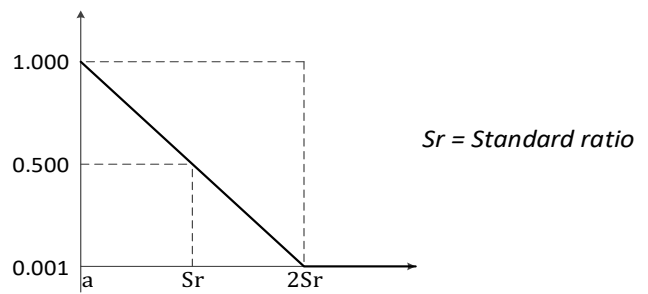

Gambar 5. Representasi matriks keputusan linear turun

Fungsi matriks keputusan linear naik:

$$
\mu[\mathrm{x}]= \begin{cases}1.000 ; & x \leq a \\ (2 S r-x) /(2 S r-a) ; & a \leq x \leq b \\ 0.001 ; & x \geq b\end{cases}
$$

dimana $\mathrm{a}=0$, nilai $\mu[\mathrm{x}]$ tidak boleh kurang dari 0.001 .

Dari perhitungan menggunakan representasi linear diatas didapatkan nilai matriks keputusan dalam bentuk bilangan fuzzy dengan tingkat presisi tiga digit desimal seperti terlihat dalam Tabel 3.

Tabel 3. Hasil matriks keputusan dalam bilangan fuzzy

\begin{tabular}{|c|c|c|r|r|r|r|r|r|}
\hline \multirow{2}{*}{ Kriteria } & \multirow{2}{*}{$\begin{array}{c}\text { Jenis } \\
\text { Atribut }\end{array}$} & \multirow{2}{*}{$\begin{array}{l}\text { Fungsi } \\
\text { Linear }\end{array}$} & \multicolumn{1}{l}{ Standard } & \multicolumn{6}{|c|}{ Ratio } & BSilangan Fuzzy & BSDE & KIJA & SMRA & WIKA \\
\hline C1 & benefit & naik & 1.70 & 0.221 & 0.784 & 0.843 & 0.377 & 0.322 \\
\hline C2 & benefit & naik & 1.50 & 0.001 & 0.604 & 0.822 & 0.225 & 0.314 \\
\hline C3 & benefit & naik & 0.50 & 0.239 & 0.976 & 0.340 & 0.505 & 0.190 \\
\hline C4 & cost & turun & 0.60 & 0.475 & 0.662 & 0.589 & 0.451 & 0.380 \\
\hline C5 & cost & turun & 0.60 & 0.001 & 0.431 & 0.190 & 0.001 & 0.001 \\
\hline C6 & cost & turun & 0.50 & 0.001 & 0.648 & 0.447 & 0.150 & 0.359 \\
\hline C7 & cost & turun & 1.00 & 0.001 & 0.159 & 0.014 & 0.001 & 0.001 \\
\hline C8 & benefit & naik & 25.00 & 1.000 & 1.000 & 0.219 & 0.403 & 0.100 \\
\hline C9 & benefit & naik & 17.00 & 0.018 & 0.013 & 0.070 & 0.019 & 0.275 \\
\hline C10 & benefit & naik & 7.00 & 0.078 & 0.040 & 0.041 & 0.048 & 0.111 \\
\hline C11 & benefit & naik & 3.00 & 0.813 & 1.000 & 0.212 & 1.000 & 1.000 \\
\hline C12 & benefit & naik & 2.00 & 0.073 & 0.073 & 0.089 & 0.083 & 0.252 \\
\hline C13 & benefit & naik & 0.20 & 0.187 & 0.322 & 0.032 & 0.201 & 0.124 \\
\hline C14 & benefit & naik & 0.30 & 0.338 & 0.361 & 0.042 & 0.392 & 0.322 \\
\hline C15 & benefit & naik & 0.28 & 0.891 & 1.000 & 0.764 & 0.938 & 0.199 \\
\hline C16 & benefit & naik & 0.23 & 0.905 & 1.000 & 0.679 & 0.715 & 0.222 \\
\hline C17 & benefit & naik & 0.20 & 0.734 & 1.000 & 0.095 & 0.669 & 0.131 \\
\hline C18 & cost & turun & 8.00 & 0.398 & 0.289 & 0.001 & 0.362 & 0.001 \\
\hline C19 & cost & turun & 6.00 & 0.868 & 0.810 & 0.923 & 0.799 & 0.749 \\
\hline
\end{tabular}

\section{Menentukan bobot preferensi kriteria}

Berdasarkan hasil observasi pada dokumen Keputusan Menteri BUMN No : KEP-100/MBU/2002 dan Peraturan Menteri BUMN Nomor : PER-10/MBU/2014 tentang Indikator Penilaian Tingkat Kesehatan BUMN, maka bobot preferensi setiap kriteria terlihat pada Tabel 4 .

Tabel 4. Bobot preferensi setiap kriteria

\begin{tabular}{|l|r|r|r|r|r|r|r|}
\hline KRITERIA & $\mathrm{C} 1$ & $\mathrm{C} 2$ & $\mathrm{C} 3$ & $\mathrm{C} 4$ & $\mathrm{C} 5$ & $\mathrm{C} 6$ & $\mathrm{C} 7$ \\
\hline BOBOT & 0.067 & 0.067 & 0.067 & 0.075 & 0.075 & 0.075 & 0.075 \\
\hline TIPE & benefit & benefit & benefit & cost & cost & cost & cost \\
\hline
\end{tabular}

\begin{tabular}{|l|r|r|r|r|r|r|r|}
\hline KRITERIA & C8 & C9 & C10 & C11 & C12 & C13 & C14 \\
\hline BOBOT & 0.040 & 0.040 & 0.040 & 0.040 & 0.040 & 0.040 & 0.040 \\
\hline TIPE & benefit & benefit & benefit & benefit & benefit & benefit & benefit \\
\hline
\end{tabular}

\begin{tabular}{|l|r|r|r|r|r|}
\hline KRITERIA & $\mathrm{C} 15$ & $\mathrm{C} 16$ & $\mathrm{C} 17$ & $\mathrm{C} 18$ & $\mathrm{C} 19$ \\
\hline BOBOT & 0.040 & 0.040 & 0.040 & 0.050 & 0.050 \\
\hline TIPE & benefit & benefit & benefit & cost & cost \\
\hline
\end{tabular}




\section{Membuat matriks keputusan ternormalisasi}

Matriks keputusan ternormalisasi dapat dikalkulasi berdasarkan metode SAW dengan persamaan (3) dan (4) seperti contoh berikut;

$$
\begin{array}{ll}
C 1=\text { benefit }, \text { maka }: & C 4=\text { cost }, \text { maka }: \\
r_{11}=\frac{0.221}{0.843}=0.263 ; & r_{14}=\frac{0.380}{0.475}=0.801 ; \\
\mathrm{dst} ; & \mathrm{dst} ;
\end{array}
$$

sehingga didapatkan hasil keseluruhan dari perhitungan matriks keputusan seperti yang terlihat pada Tabel 5 dengan tingkat presisi 3 digit desimal.

Tabel 5. Hasil perhitungan matriks ternormalisasi

\begin{tabular}{|l|l|l|l|l|l|l|l|}
\hline ALTERNATIF & $\mathrm{C} 1$ & $\mathrm{C} 2$ & $\mathrm{C} 3$ & $\mathrm{C} 4$ & $\mathrm{C} 5$ & $\mathrm{C} 6$ & $\mathrm{C} 7$ \\
\hline ASRI & 0.263 & 0.001 & 0.245 & 0.801 & 1.000 & 1.000 & 1.000 \\
\hline BSDE & 0.930 & 0.734 & 1.000 & 0.574 & 0.002 & 0.002 & 0.006 \\
\hline KIJA & 1.000 & 1.000 & 0.348 & 0.645 & 0.005 & 0.002 & 0.072 \\
\hline SMRA & 0.447 & 0.273 & 0.517 & 0.843 & 1.000 & 0.007 & 1.000 \\
\hline WIKA & 0.382 & 0.382 & 0.195 & 1.000 & 1.000 & 0.003 & 1.000 \\
\hline
\end{tabular}

\begin{tabular}{|l|c|c|c|c|c|c|c|}
\hline ALTERNATIF & C8 & C9 & C10 & C11 & C12 & C13 & C14 \\
\hline ASRI & 1.000 & 0.064 & 0.705 & 0.813 & 0.289 & 0.582 & 0.862 \\
\hline BSDE & 1.000 & 0.047 & 0.363 & 1.000 & 0.290 & 1.000 & 0.921 \\
\hline KIJA & 0.219 & 0.253 & 0.372 & 0.212 & 0.355 & 0.098 & 0.106 \\
\hline SMRA & 0.403 & 0.071 & 0.427 & 1.000 & 0.332 & 0.623 & 1.000 \\
\hline WIKA & 0.100 & 1.000 & 1.000 & 1.000 & 1.000 & 0.385 & 0.822 \\
\hline
\end{tabular}

\begin{tabular}{|l|c|c|c|c|c|}
\hline ALTERNATIF & C15 & C16 & C17 & C18 & C19 \\
\hline ASRI & 0.891 & 0.905 & 0.734 & 0.003 & 0.864 \\
\hline BSDE & 1.000 & 1.000 & 1.000 & 0.003 & 0.926 \\
\hline KIJA & 0.764 & 0.679 & 0.095 & 1.000 & 0.812 \\
\hline SMRA & 0.938 & 0.715 & 0.669 & 0.003 & 0.938 \\
\hline WIKA & 0.199 & 0.222 & 0.131 & 1.000 & 1.000 \\
\hline
\end{tabular}

\section{Membuat matriks keputusan normalisasi terbobot}

Bobot preferensi yang telah ditentukan sebelumnya akan digunakan untuk menentukan nilai-nilai matriks normalisasi terbobot, dengan perhitungan menggunakan persamaan (7) seperti contoh berikut;

$$
\begin{array}{ll}
\mathrm{Y}_{11}=0.067 * 0.263 & \mathrm{Y}_{12}=0.067 * 0.001 \\
\mathrm{Y}_{11}=0.018 ; & \mathrm{Y}_{12}=0.000 ; \mathrm{dst} ;
\end{array}
$$

maka diperoleh hasil keseluruhan seperti yang tertampil pada Tabel 6 seperti berikut:

Tabel 6. Hasil perhitungan matriks normalisasi terbobot

\begin{tabular}{|l|l|l|l|l|l|l|l|}
\hline ALTERNATIF & C1 & C2 & C3 & C4 & C5 & C6 & C7 \\
\hline ASRI & 0.018 & 0.000 & 0.016 & 0.060 & 0.075 & 0.075 & 0.075 \\
\hline BSDE & 0.062 & 0.049 & 0.067 & 0.043 & 0.000 & 0.000 & 0.000 \\
\hline KIJA & 0.067 & 0.067 & 0.023 & 0.048 & 0.000 & 0.000 & 0.005 \\
\hline SMRA & 0.030 & 0.018 & 0.034 & 0.063 & 0.075 & 0.001 & 0.075 \\
\hline WIKA & 0.025 & 0.025 & 0.013 & 0.075 & 0.075 & 0.000 & 0.075 \\
\hline
\end{tabular}

\begin{tabular}{|l|l|l|l|l|l|l|l|}
\hline ALTERNATIF & C8 & C9 & C10 & C11 & C12 & C13 & C14 \\
\hline ASRI & 0.040 & 0.003 & 0.028 & 0.033 & 0.012 & 0.023 & 0.034 \\
\hline BSDE & 0.040 & 0.002 & 0.015 & 0.040 & 0.012 & 0.040 & 0.037 \\
\hline KIJA & 0.009 & 0.010 & 0.015 & 0.008 & 0.014 & 0.004 & 0.004 \\
\hline SMRA & 0.016 & 0.003 & 0.017 & 0.040 & 0.013 & 0.025 & 0.040 \\
\hline WIKA & 0.004 & 0.040 & 0.040 & 0.040 & 0.040 & 0.015 & 0.033 \\
\hline
\end{tabular}

\begin{tabular}{|l|c|c|c|c|c|}
\hline ALTERNATIF & $\mathrm{C} 15$ & $\mathrm{C} 16$ & $\mathrm{C} 17$ & $\mathrm{C} 18$ & $\mathrm{C} 19$ \\
\hline ASRI & 0.036 & 0.036 & 0.029 & 0.000 & 0.043 \\
\hline BSDE & 0.040 & 0.040 & 0.040 & 0.000 & 0.046 \\
\hline KIJA & 0.031 & 0.027 & 0.004 & 0.050 & 0.041 \\
\hline SMRA & 0.038 & 0.029 & 0.027 & 0.000 & 0.047 \\
\hline WIKA & 0.008 & 0.009 & 0.005 & 0.050 & 0.050 \\
\hline
\end{tabular}

\section{Menentukan matriks solusi ideal positif dan negatif}

Untuk menentukan nilai-nilai dalam matriks solusi ideal perlu diperhatikan sifat masing-masing kriteria, apakah bersifat keuntungan (benefit) atau bersifat biaya (cost). Dengan memperhatikan tipe kriteria pada Tabel 4 maka dapat ditentukan hasil matriks solusi ideal positif dan solusi ideal negatif seperti tertampil pada Tabel 7.

Tabel 7. Hasil solusi ideal positif dan solusi ideal negatif

\begin{tabular}{|l|l|l|l|l|l|l|l|}
\hline SOLUSI IDEAL & $\mathrm{C} 1$ & $\mathrm{C} 2$ & $\mathrm{C} 3$ & $\mathrm{C} 4$ & $\mathrm{C} 5$ & $\mathrm{C} 6$ & $\mathrm{C} 7$ \\
\hline $\mathrm{A}+$ & 0.067 & 0.067 & 0.067 & 0.043 & 0.000 & 0.000 & 0.000 \\
\hline $\mathrm{A}-$ & 0.018 & 0.000 & 0.013 & 0.075 & 0.075 & 0.075 & 0.075 \\
\hline
\end{tabular}

\begin{tabular}{|l|l|l|l|l|l|l|l|}
\hline SOLUSI IDEAL & C8 & C9 & C10 & C11 & C12 & C13 & C14 \\
\hline $\mathrm{A}+$ & 0.040 & 0.040 & 0.040 & 0.040 & 0.040 & 0.040 & 0.040 \\
\hline $\mathrm{A}-$ & 0.004 & 0.002 & 0.015 & 0.008 & 0.012 & 0.004 & 0.004 \\
\hline
\end{tabular}

\begin{tabular}{|l|c|c|c|c|c|}
\hline SOLUSI IDEAL & $\mathrm{C} 15$ & $\mathrm{C} 16$ & $\mathrm{C} 17$ & $\mathrm{C} 18$ & $\mathrm{C} 19$ \\
\hline $\mathrm{A}+$ & 0.040 & 0.040 & 0.040 & 0.000 & 0.041 \\
\hline $\mathrm{A}-$ & 0.008 & 0.009 & 0.004 & 0.050 & 0.050 \\
\hline
\end{tabular}

\section{Menentukan jarak antara nilai setiap alternatif}

Penghitungan jarak euclidean terbobot terhadap solusi ideal positif dengan persamaan (10) dan terhadap solusi ideal negatif dengan persamaan (11) maka didapatkan nilai untuk masing-masing alternatif seperti yang terlihat pada Tabel 8.

Tabel 8. Hasil perhitungan jarak euclidean terbobot

\begin{tabular}{|l|r|r|}
\hline \multicolumn{1}{|c|}{ ALTERNATIF } & D & \multicolumn{1}{c|}{ D- } \\
\hline ASRI & 0.171 & 0.091 \\
\hline BSDE & 0.057 & 0.188 \\
\hline KIJA & 0.113 & 0.157 \\
\hline SMRA & 0.142 & 0.117 \\
\hline WIKA & 0.162 & 0.106 \\
\hline
\end{tabular}

\section{Menentukan nilai preferensi untuk setiap alternatif}

Untuk menentukan peringkat masing-masing alternatif yang ada maka perlu dihitung terlebih dahulu nilai preferensi dari setiap alternatif. Dengan perhitungan berdasarkan persamaan (12) seperti contoh berikut;

$$
\begin{aligned}
& V_{1}=\frac{0.091}{0.091+0.171} \\
& V_{1}=0.347 ; \mathrm{dst} ;
\end{aligned}
$$

maka didapatkan hasil nilai preferensi dan ranking untuk masing-masing alternatif seperti terlihat pada Tabel 9.

Tabel 9. Hasil perhitungan nilai preferensi dan ranking

\begin{tabular}{|l|r|c|}
\hline \multicolumn{1}{|c|}{ ALTERNATIF } & \multicolumn{1}{c|}{ V } & Peringkat Rekomendasi \\
\hline ASRI & 0.347 & 5 \\
\hline BSDE & 0.767 & 1 \\
\hline KIJA & 0.582 & 2 \\
\hline SMRA & 0.453 & 3 \\
\hline WIKA & 0.395 & 4 \\
\hline
\end{tabular}

Dengan perhitungan menggunakan metode SAWTOPSIS didapatkan keputusan bahwa alternatif ke-2 yaitu saham Bumi Serpong Damai Tbk. (BSDE) yang memiliki laporan keuangan terbaik pada tahun 2013 dibandingkan alternatif lainnya, sehingga dapat menjadi rekomendasi terbaik untuk berinvestasi saham di tahun 2014. 


\subsection{Pengujian}

Dari hasil pengujian akurasi dengan membandingkan hasil pemeringkatan (scoring) berdasarkan model Springate dengan metode SAW-TOPSIS terhadap datadata penelitian maka didapatkan hasil pengujian akurasi seperti Tabel 10 dan grafik perbandingan hasil pengujian dapat dilihat pada Gambar 10.

Tabel 10. Hasil akurasi pengujian data

\begin{tabular}{|c|l|c|c|}
\hline No & \multicolumn{1}{|c|}{ Sektor } & Tahun & Akurasi \\
\hline 1 & Properti & 2013 & $90.00 \%$ \\
\hline 2 & Properti & 2014 & $90.00 \%$ \\
\hline 3 & Properti & 2015 & $90.00 \%$ \\
\hline
\end{tabular}



Gambar 6. Grafik pengujian data

\section{Kesimpulan}

Berdasarkan pembahasan dalam penelitian dapat diambil beberapa kesimpulan diantaranya:

1. Penerapan SAW-TOPSIS dalam analisis rasio keuangan untuk menunjang keputusan berinvestasi saham dapat dilakukan dengan cara menghitung nilai rasio keuangan sebagai kriteria, memberi bobot masing-masing kriteria, menormalisasikan nilai hasil rasio keuangan ke dalam bentuk bilangan fuzzy berdasarkan standar rasio keuangan, membentuk matriks keputusan, menormalisasikan matriks keputusan berdasarkan metode SAW, membuat matriks ternormalisasi terbobot, menentukan matriks solusi ideal positif dan negative, menentukan jarak antara nilai setiap alternatif, dan menghitung nilai preferensi setiap alternatif $(\mathrm{Vi})$ untuk dibandingkan.

2. Berdasarkan pengujian akurasi metode SAW-TOPSIS menggunakan uji koefisien korelasi pemeringkatan Spearman berdasarkan model Springate pada skenario 1 didapatkan tingkat akurasi pemeringkatan tertinggi yakni sebesar $100 \%$ dan terendah $90 \%$.

3. Tingkat hasil akurasi pada penelitian ini dapat berubah-ubah mengikuti nilai bobot preferensi yang diberikan pada setiap kriteria dan juga jumlah alternatif data yang diuji.

4. Sistem Pendukung Keputusan yang dikembangkan dalam penelitian ini dapat mengakomodasi pemeringkatan alternatif saham dan memberikan hasil rekomendasi terbaik untuk berinvestasi.

\section{Daftar Pustaka}

[1] Fakhruddin, Hendy M., Istilah Pasar Modal A-Z, Jakarta: Elex Media Komputindo, 2008.

[2] Hery., Analisis Laporan Keuangan Pendekatan Rasio Keuangan, Yogyakarta: CAPS, 2015.

[3] S, Henry Wibowo, "MADM-Tool:Aplikasi Uji Sensitivitas untuk Model MADM Menggunakan Metode SAW dan TOPSIS", in Proc. Seminar Nasional Aplikasi Teknologi Informasi 2010, ISSN: 19075022, 2010.

[4] Setyawan, Yan Satria, et all., 'Implementasi Metode Fuzzy Analytical Hierarchy Process (F-AHP) Sebagai Pendukung Keputusan Investasi Pada Perusahaan Berdasarkan Rasio Keuangan (Studi Pada Perusahaan Farmasi Yang Terdaftar di BEI Periode 2013)", Jurnal PTIIK Universitas Brawijaya, vol. 5, no. 10, 2013.

[5] Heri., Analisis Laporan Keuangan Pendekatan Rasio Keuangan, Yogyakarta: CAPS, 2015.

[6] Wahyudiono, Bambang., Mudah Membaca Laporan Keuangan, Jakarta: Raih Asa Sukses, 2014.

[7] Irwansyah, Edy, dan Muhammad Faisal., Advanced Clustering: Teori dan Aplikasi, Yogyakarta: Deepublish, 2015.

[8] Nofriansyah, Dicky., Konsep Data Mining vs Sistem Pendukung Keputusan, Yogyakarta: Deepublish, 2014.

[9] Vickers, Frank., The Dynamic Small Business Manager, United States: Lulu Press, 2006.

[10] Siagian, Dergibson, dan Sugiarto., Metode Statistika Untuk Bisnis dan Ekonomi, Jakarta: Gramedia Pustaka Utama, 2006.

\section{Biodata Penulis}

Angger Binuko Paksi, memperoleh gelar Sarjana Komputer (S.Kom), Jurusan Teknik Informatika STMIK AMIKOM Yogyakarta, lulus tahun 2014. Saat ini sedang menempuh studi pada Program Pasca Sarjana Magister Teknik Informatika di STMIK AMIKOM Yogyakarta dan bekerja sebagai freelancer dengan fokus di bidang Android Aplication Developer.

Ema Utami, memperoleh gelar Sarjana Sains (S.Si), Jurusan Ilmu Komputer Universitas Gajah Mada Yogyakarta, lulus tahun 1997. Memperoleh gelar Magister Ilmu Komputer (M.Kom) Program Pasca Sarjana Magister Ilmu Komputer Universitas Gajah Mada Yogyakarta, lulus tahun 2002. Memperoleh gelar Doktor (Dr) Program S3 Ilmu Komputer Universitas Gajah Mada Yogyakarta, lulus tahun 2010. Saat ini menjadi Dosen dan juga Wakil Direktur I Bidang Akademik Magister Teknik Informatika STMIK AMIKOM Yogyakarta.

Henderi, memperoleh gelar Sarjana Komputer (S.Kom), Jurusan Sistem Informasi Universitas Bina Darma Palembang, lulus tahun 2000. Memperoleh gelar Magister Komputer (M.Kom) Program Pasca Sarjana Magister Teknik Informatika STTI Benarif Indonesia Jakarta, lulus tahun 2006. Saat ini menjadi Dosen di STMIK AMIKOM Yogyakarta dan juga sedang menempuh program S3 Ilmu Komputer Universitas Gadjah Mada Yogyakarta. 